\title{
Exploring the trauma care nurse's lived experiences of dealing with the violent death of their clients.
}

\author{
P Brysiewicz, MCur, School of Nursing, University of Natal - Durban \\ BR Bhengu, MCur, School of Nursing, University of Natal - Durban
}

\begin{abstract}
A phenomenological approach was used to explore the phenomenon, violent death, from the perspective of trauma care nurses working in Kwa-Zulu Natal. Three relatively unstructured interviews were undertaken on an individual basis with each lasting thirty to forty-five minutes long. The researchers applied the principle of theoretical saturation and a total of seven participants from three levelone trauma units were included in the study. All the interviews were tape recorded and transcribed, and manual analysis, as well as a qualitative software package NUD*IST - was used to identify experiential themes within the data.

The trauma care nurses conceptualized violent death as being sudden, unpredictable, senseless and not as dignified or peaceful as a non-violent death. A number of issues that made confronting violent death difficult were raised and the trauma care nurses described a number of emotional and physical reactions that they experienced due to exposure to these situations. A number of recommendations were suggested for the trauma care nurses, nursing management, nurse educators and for future research in an attempt to prevent the loss of these valuable nurses from the nursing profession.
\end{abstract}

\section{Abstrak}

'n Fenomenologiese benadering was benut om die verskynsel van geweldadige dood vanuit die perspektief van trauma verpleegkundiges werksaam in Kwa-Zulu Natal te ondersoek. Drie relatief ongestruktureerde onderhoude is op ' $n$ individuele basis met elke deelnemer, van ongeveer dertig tot veertig minute elk, gevoer. Die navorsers het die beginsel teoretiese versadiging toegepas en ' $n$ totaal van sewe deelnemers vanuit vlak een traumaeenhede was in die studie ingesluit. Al die onderhoude is op audio band opgeneem en getranskribeer. Beide manuele analise, sowel as wel as die kwalitatiewe sagteware paket - NUD*IST - was gebruik om ervarings temas in die data te identifiseer.

Die trauma verpleegkundige sien geweldadige dood as " $n$ skielike, onvoorspelbare, sinnelose en nie so waardig of vreedsaam soos ' $n$ nie-geweldadige dood. 'n Aantal kwessies wat konfrontasie met geweldadige dood bemoeilik is deur die trauma verpleegkundiges geidentifiseer asook ' $n$ aantal emosionele en fisiese reaksies wat ervaar was gedurende die blootstelling aan hierdie situasies. Ter voorkoming van die verlies van hierdie waardevolle verpleegkundiges vanuit die verpleegprofessie, word ' $n$ aantal aanbevelings aan trauma-verpleegkundiges; verpleegbestuurders, verpleegdosente en vir toekomstige navorsing gemaak.

\section{Introduction}

Violence is said to be the leading cause of injury severity in South Africa and the 1996 homicide rate of 61 per 100000 placed South Africa among the most violent countries of the world (Marais, 1998). Trauma in the province of KwaZulu Natal is considered to be a huge problem with violent deaths being the highest of all causes of death in the Durban metropolitan area. In a study carried out by Meumann \& Peden (1997) in the Durban metropolitan area focusing on one state and one private hospital, it was found that $32.2 \%$ of the reported deaths were traffic - related deaths and $13.1 \%$ were said to be due to an accident. The remaining $54.7 \%$ of the reported deaths was due to violence $-90.4 \%$ of the victims had reportedly been assaulted and $9.6 \%$ had committed suicide. Almost half of the assault cases had died from firearm injury, but sharp objects (for example stabs) also accounted for a significant proportion of these deaths. Another disturbing factor of the results was that the average age amongst the total 398 cases was 33.6 years (Meumann \& Peden, 1997). Nationally, trauma care nurses are faced with traumatic deaths on a regular basis and added to this is the fact that the majority of these deaths are of young adults in the prime of their life. It is acknowledged that the work of the trauma nurse is extremely stressful and can lead to burnout, acute stress disorders or Post-Traumatic Stress Disorder. Increased awareness of the influence that the constant confrontation with violent death has or can have on the trauma staff is of great importance, in order to protect the staff involved.

\section{Purpose of the research}

The purpose of the study was to explore the lived experiences of these trauma care nurses who are constantly being confronted with the violent death of their clients. 


\section{Operational concepts}

\section{Violent death}

The sudden and unforeseen loss of life, which results in a body (corpse) which may be mutilated or horrible to look at. The death was not a peaceful one and in some cases, it could have been prevented (Ruby, 1998). These deaths usually took place in the trauma units or within approximately two hours of handing the patient over to either critical care or theatre personnel.

\section{Level - one trauma unit}

Level-one trauma units are nationally recognized as specialized trauma units due to the fact that they adhere to specified requirements. These units have a minimum quota of trauma qualified and/or experienced staff (both nurses and doctors) as well as specialized resources and necessary equipment available to deal with severely physically traumatized clients.

\section{Trauma care nurse}

A nurse, who is recognized by the South African Nursing Council as a registered nurse, and has worked in a recognized level-one trauma department for a minimum of one year. The nurse may or may not have undergone further trauma or emergency care training.

\section{Clients}

The individuals who interact with the personnel working in the trauma units either as a patient, a family member or significant others.

\section{Dealing (with violent death)}

Being exposed to the reality of violent death and providing or involved in the emergency care rendered to the person dying, or to the patient with a high likelihood of dying due to the presenting clinical signs and symptoms. May be exposed to the body (corpse) and the significant others. It also involves managing the effects of this exposure and involvement in one's personal and working life.

\section{Ethical considerations}

Permission was obtained from the provincial authorities, as well as the board of management of the private hospital, prior to approaching the participants. The selection of participants was done on a strictly voluntary basis and the participant's real name was not used in the interviews - the participants were asked to choose a pseudonym. The researchers attempted to establish rapport with the participants and also discussed with the participants the issue of secrets and maintaining confidentiality. Support was given to the participants by the researchers due to the sensitive nature of the phenomenon being explored, by allowing time for debriefing after the interview. The researchers were aware that hospital counsellors were available and one researcher had basic Mental Health training which enabled the identification of those participants who might require further psychological support. The participants were informed of their right to withdraw from the research at any time. The recordings of the interviews were only accessible to the researchers and the person helping with the transcribing. Once the raw data from the taped interviews was imported into the computer package all the taped interviews were destroyed. The raw files were identified using the pseudonyms only; thus the data could not be traced back to the participant.

\section{Research design}

A qualitative research design was chosen for this study as this is considered to be a holistic research approach, which allows the researcher to gain a full view of the phenomenon under study. Qualitative research is also descriptive, and is an excellent way of obtaining information and exploring a particular phenomenon (Polit \& Hungler, 1993). A phenomenological approach was used in this qualitative research, to explore from the perspective of the trauma care nurses themselves, their experiences of being confronted with the violent death of their clients.

\section{The selection of participants}

Scientific purposive sampling was used as the researchers considered registered nurses working in recognized level-one trauma units, with at least one year of working experience in the trauma departments, for inclusion in the study. This was due to the fact that the researchers wanted to include trauma care nurses who had sufficient experience of confronting violent deaths within the trauma unit environment. Registered nurses working in one private and two state level-one trauma units were considered for inclusion in the study.

\section{Credibility}

Credibility was obtained by prolonged engagement as the researchers spent a great deal of time interviewing the participants in the field. These interviews were conducted over a period of time (about six months) and the researchers interviewed all the participants. At each interview the researchers confirmed the findings from the previous interview with the participants in order to ensure that the results were in fact a true reflection of the participants experiences (Brink, 1993). The researchers also attempted to give the reader a sense of being there and truly experiencing the research for themselves by giving in-depth descriptions of the events. The researchers remained in the field collecting data until no new information was being obtained. This is referred to as saturation and is seen as the sense of closure that the researchers experience when the data collection fails to yield any new information (Polit \& Hungler, 1993:333).

"Thick" descriptions of the research process and of the data provided by the participants was given, thus the researchers endeavoured to demonstrate mastery of the chosen research method. When documentation was taking place the researchers were rigorous and ensured that all steps and decisions taken during the research were written down and a motivation was given (van der Merwe, 1996). Data was also triangulated with relevant data from the literature. An experienced qualitative researcher monitored the relevance and appropriateness of the categories and themes, which the researchers derived from the data. The researchers were very aware of the possibility of introducing bias and attempted at all times to guard against this (Brink, 1993).

\section{Data collection}

The researchers developed a crude outline of the key areas of 
the research in an attempt to guide the interviews, although this guideline was very flexible and open to any changes that the researchers or the participants wished to make. As the research "instrument", the researchers used the responses of the participants to guide the data collection, exploring for further information as needed for depth and clarity. The seven participants who volunteered were asked to participate in three individual interviews each using open-ended questions, which allowed for the exploration of themes and ideas expressed by the participants.

The first interview included an introduction of the participant's experiences with confronting violent death as well as their conceptualization of violent death. The second interview was concerned with the effect that the confrontation with violent death had on the participants in their working and personal lives. The third interview allowed for the researchers as well as the participant to clarify any issues and questions which had arisen from the previous interviews, and for closure. This interview attempted to deal with the management of and exploring possible strategies to prevent the negative effects of being confronted with violent death.

\section{The participants}

The researchers interviewed a total of seven trauma care nurses working at three level-one trauma units in the Durban Metropolitan area. Eighteen interviews were conducted with an average of two-and-a-half interviews per participant at two to three weekly intervals. One of the participants (JANE) chose to withdraw from the interviews and another participant, MARY, had only one interview due to extreme difficulties faced by the researchers in trying to select an appropriate time to interview her. The participants were very enthusiastic regarding the research and expressed their concerns to the researchers that there did not appear to be much recognition (financial or otherwise) for the difficult job they are doing under, what is usually, very trying circumstances.

During the interviews the participants displayed a variety of emotions; sometimes laughing, crying or clapping their hands in order to emphasize a particular aspect. Due to the emotional nature of the phenomena being explored the researchers set aside time at the end of the interview to debrief the participants before they went back to work. Some of the participants were very emotional at the end of the interview due to the experiences they had been discussing and this time was essential to talk to them or just to listen. The debriefing period lasted five to ten minutes and this allowed time for the participants to regain their composure before returning to their colleagues. The researchers also ensured that the room used to interview the participants was private and unoccupied for a certain length of time. A note was put on the door informing people that an interview was being conducted inside, in an attempt to prevent interruptions.

The researchers were actively involved in transcribing the taped interviews into text and found that this was an extremely time consuming exercise although it was also very beneficial. It allowed the researchers to get involved with the narratives in a very active way and facilitated the immersion of self within the text. The data was then carefully analysed manually, as well as by using a computer package for the analysis of qualitative data - NUD*IST 4 (Non-numerical Unstructured Data Indexing Searching \& Theorizing). The researchers organ- ized the data by identifying meaning units, which were then categorized or coded (Creswell, 1998). All data within the same category was then grouped and sub-categories as needed were developed. The researchers developed four broad categories namely: how the trauma care nurses conceptualise violent death, confronting the scene, dealing with the violent death of a client and support of the trauma care nurse. The researchers attempted to validate the data by moving backwards and forwards between the raw data and the categorized data in NUD*IST 4. Data documents were then compared in order to establish common as well as unique themes, and patterns within these themes (Burns \& Grove, 1995). Silence within the text was identified by (SILENCE) and this tended to occur when the subject was too painful to dwell on or the issue was very important to the participant.

\section{Findings and discussion Conceptualization of violent death.}

The participants conceptualized a violent death as being sudden, unpredictable, unexpected and thus very difficult for the family, as well as the trauma care nurse, to deal with. This is supported by Solursh (1990) who described a traumatic death as a sudden and unanticipated event, which was out of the control of the client's family. The corpse of the client was often disfigured and suggested to the participants that the death had not been peaceful or dignified.

There was consensus among the participants that gunshots, stabbings, assault and motor vehicle collisions that resulted in death, were indeed what constituted a violent death. The death of the client was also viewed as being senseless, as there were numerous occasions mentioned where there appeared to be no reason for the death. A non-violent death was also viewed as different from a violent death in that the death was often peaceful and dignified, and in many cases, expected by the family.

\section{Issues that made confronting violent death difficult to deal with}

The participants described for the researchers a number of issues that made confronting violent death difficult to deal with in the trauma units.

Dealing with the client was viewed by the trauma care nurse as being an extremely difficult situation to confront, especially if the client was conscious and aware of his/her impending death. The age of the client was also identified as a problem in that children are innocent and are not suppose to die before their parents, which then makes their premature death very difficult to accept. It is well documented in the literature that dealing with a dying child is an extremely difficult situation to cope with - both in the interaction with the client as well as the client's family (Burns \& Harm, 1993; Hattingh, 1993; Coolican, 1994; Smith, 1995 \& Payne, Dean \& Kalus, 1998). Mangini, Confessore, Girard \& Spadola, (1995) go further to say that repeated exposure to the death of children can have detrimental effects on the health care workers if they do not receive adequate support.

The participants mentioned a number of difficulties experienced when dealing with the relatives of the client and this compares with a study documented by Payne et al (1998) who showed that some of the most difficult experiences faced by 
the trauma care nurses were ones spent with the bereaved relatives. The level of education of the family also posed problems for the trauma care nurse as THANDI described how the family could not understand the life saving treatment being administered to their family member, and then accused the nurses of killing their family member.

"Death-telling" was expressed by the participants as being an extremely stressful situation to be involved in as the nurse was then faced with grieving, angry or disbelieving relatives that she then had to try and console, an issue supported in the literature by McQuay, Schwartz, Goldblatt \& Giangrasso. (1995).

Dealing with the death of a colleague or a colleague's family member was seen as being extremely stressful for the trauma care nurses, and this was documented by Dietrich \& Hattingh (1993) who suggested that this situation gives rise to extremely strong emotional reactions in the health professionals. The trauma care nurses also described a number of situations they experienced in the trauma unit which they personally identified with, these brought the experiences "close to home" for them. This then made the client's death all that much harder to deal with as it was so close to the nurse's own situation (Solursh, 1990).

\section{Emotional and physical reactions}

The participants expressed that they felt guilt, sadness and anger when dealing with the client who was dead or dying a violent death and this was supported by Mangini et al (1995) who explained that the trauma care nurses are not immune to feelings of helplessness and despair.

The participants also described a number of emotional and physical reactions that they experienced when confronted with a critical incident, that is, an extremely stressful event that has the potential to cause unusually strong emotional reactions and can lead to the development of Post Traumatic Stress Disorder (PTSD) (Stamm, 1998). Baldwin (1998) comments that the main symptoms of PTSD are intrusions, avoidance and hyper-arousal. Examples of intrusion are flashbacks and nightmares where the event is re-experienced, and a number of the participants (JANE, LYNN and TULIP) described these symptoms to the researchers. Baldwin (1998) concludes by suggesting the hyper-arousal is manifested by signs of increased arousal such as hyper-vigilance. This was evident in a number of the interviews carried out with LYNN, who demonstrated non-verbal cues of hyper-arousal. She also explained to the researchers that due to her work as a trauma care nurse, she was now extremely over protective of her own child, often to the irritation of her husband.

\section{Teamwork in confronting the scene}

The trauma care nurses were of the opinion that teamwork had both a positive and a negative influence on their daily lives. Working together as a team was useful as the staff got to know each other well and were thus able to help and support each other. THANDI described to the researchers that "even when you are busy resuscitating with the doctors, you find that it's very easy resuscitating with the people that you know, because you know their liking". The doctor - nurse relationship was also identified by THANDI as being a source of stress, as she felt that her numerous years of experience in the trauma unit were never taken into account as she was not included in any decision-making. She felt that this under- mined her position as a senior nurse in charge of the unit and thus impaired the functioning of the health care team, possibly to the detriment of their clients. Helps (1997) concluded in a study that team cohesion and interpersonal relationships with colleagues were both a source of stress and satisfaction, thus within the environment of trauma it is essential that there be good working relations and that the members of the team recognise each other's stress.

\section{Ways of dealing with the constant presence of violent death. Death beliefs}

The participants described for the researchers a number of death beliefs that they held which helped them to deal with the difficult situations they were faced with. Some of the participants described their various religious beliefs and occasions where they had been praying over the client, whereas other participants were of the opinion that the client's death was predetermined and nothing could be done to change the outcome. Caring for the dying is a particularly demanding area of nursing and it has been suggested that the personal attitudes that one holds about death and dying strongly influence how one lives and works (Payne et al, 1998). Whittle (1999) suggests that unless the health workers are able to work through their own thoughts and feelings about death and dying, they will not be able to efficiently help their clients.

\section{Physical and emotional avoidance}

Some of the participants described for the researchers how there were various situations that they were unable to deal with (the most common being the death of a child) and thus avoided this situation, either physically or emotionally. Avoidance, is viewed by Baldwin (1998), as being evident where the trauma care nurse tries to reduce the exposure to people or things that might bring on their intrusive symptoms. This use of "avoidance" is documented in the literature by Payne et al (1998) and a review of literature by Neimeyer (1994) also indicates that health professionals with high levels of death anxiety are more likely to use 'avoiding' coping strategies. During the interviews with MERCIA, the researchers also became aware of the use of escapism in that the participant described how she would often just go home and sleep, and wake up in the morning feeling much better about the situation (Aldwin \& Revenson, 1987).

The unemotional nature of the trauma care nurse is well documented although Schwam (1998) is of the opinion that many health workers have just learnt to control and hide their feelings, and thus cope with difficult situations by avoiding it either physically or emotionally. MERCIA was of the opinion that there was no time to do otherwise, she said; "you finish the resusc, you take off your gloves, wash your hands and its either your tea-time or there's four patients waiting to be stitched ... there's a backlog of work, so you just shake it off".

Maeve (1998) also makes mention of the use of 'black humour', that is, telling jokes to boost ones courage and to make an awful situation appear silly or less real. This was again noted during the interviews by the researchers when some of the participants made jokes or laughed inappropriately while describing extremely difficult situations. 


\section{Realization of the role of the trauma care nurse}

It was suggested by TULIP, that in order to cope with the difficult situations it is important to realize that this is the nature of the work of a trauma care nurse. Payne ct al (1998) is of the opinion that trauma care nurses choose to do this work because it is extremely busy, there is a lack of routine and a variety of procedures and clients. These authors also cautions that the trauma care nurse needs to be aware of the fact that death is indeed an unfortunate consequence of this job. JOYCE agreed with this by saying "I must always tell myself that I am working in a place like this so I have to face everything that's going to happen".

\section{Possible strategies to support trauma care nurses Debriefing}

Some of the participants mentioned to the researchers that talking about the traumatic incidents that they had faced, either formally or informally, helped them to cope with the situation. Aldwin \& Revenson (1987) refer to this informal debriefing as support mobilization, where the individual makes an effort to obtain information, advise and emotional support from each other. A number of the participants interviewed were already involved in formal debriefing programs and suggested that this was indeed of great benefit to them as it allowed you to get to know your colleagues better and made you realise that you were not alone. LYNN also suggested that "with regular debriefing you get it off instead of harboring $i t$, you get it off your chest quicker". Critical Incident Stress Debriefing is a process of educating and preventing the effects from an exposure to a critical event. It requires the formation of a well trained team who lead the debriefing process, which then aims to reduce the stress caused by an extraordinary event (Burns \& Harm, 1993). These authors are of the opinion that debriefings are indeed helpful for the trauma care nurse to deal effectively with the different traumatic situations they find themselves involved in and in their study, eighty-two percent of their respondents confirmed this finding. Raphael, Meldrum \& McFarlane (1996) caution against believing all good of debriefing and suggest that it may increase problems, be inappropriate in time or format for some people and that it does not take the staff's past experiences, coping processes or life stresses into account. Raphael et al (1996) does however conclude that despite debriefing being costly and potentially ineffective, it is here to stay, for now, as it does meet some real and symbolic needs of the trauma care nurses.

\section{Death education}

Nurses who are specifically educated to meet the needs of a dying client and his/her family are likely to reflect a positive attitude towards coping with death (Corr \& Doka, 1994). In a study carried out by Tye (1993) cited in Payne ct al (1998) it was discovered that $52 \%$ of the trauma care nurses involved in the study felt unprepared to deal with sudden, traumatic deaths and the distraught relatives. JOYCE was of the opinion that the reason why trauma care nurses do not function well when faced with death in the unit was due to the fact that they have never been taught how to cope with the death of a client. She stressed the importance of orientating new staff to the unit and telling them about what they may face and not leaving them to cope with stressful situations on their own. Helping the families who have lost a loved one to a violent death can be challenging although by understanding their needs and keeping ones "death skills" up to date, it can be extremely rewarding both personally and professionally (Wheeler, 1996).

\section{Support from nursing management}

Some of the participants felt that nursing management did not appear to acknowledge the fact that working in the trauma unit was stressful for the trauma care nurses, and this then added to their stress. MERCIA felt that she was often neglected by the nursing management who according to her would come in during a resuscitation and say "look at all the cotton wool swabs on the floor!" Helps (1997) confirms this in her own study in which trauma care nurses rated an unresponsive nursing and hospital leadership as being an important source of stress. Some of the participants suggested that just by letting the trauma care nurses know that they were appreciated for doing such a difficult job would go a long way to helping to relieve some of the stress inherent in the work. Some of the participants also mentioned that nursing management should monitor stress levels in the individual staff members, encourage regular vacation and be open to rotating the trauma care nurse to other departments, if possible. It was mentioned to the researchers by some of the participants that the trauma care nurse never gets to see the clients getting better and Helps (1997) confirms that seeing clients getting better was the most frequently cited source of satisfaction for the trauma care nurses in her study.

\section{Recommendations}

Hospital chaplains or dedicated staff to deal with the families on arriving at the hospital or to contact relatives of the client, need to be made available, as the trauma care nurse is often too busy to attend adequately to this task. The formation of debriefing sessions in the trauma units needs to be initiated in order to assist the health professionals to deal adequately with the stressful nature of their daily work. Both of these recommendations were already suggested in a study carried out by Kerr (1996).

Nursing management needs to be aware of the importance of allowing the staff to see clients getting better, and efforts should be made to follow up on the clients that have survived and ensure that the trauma care nurses be made aware of their 'successes'. Nursing management should also be aware that stress disorders can lead to a decrease in job performance, staff morale and an overall decline in the health of the trauma care nurse. Attempts should be made to try and support the staff as much as possible by interviewing them on an individual basis at regular intervals, to assess the staff members stress levels and to ascertain if the nurse has any special requests, for example, rotation out of the unit for a short time. Nurse educators need to be made aware of the apparent lack of death education in the current undergraduate curriculum for nurses and this needs to be addressed. Nurse educators should also acknowledge the importance of stress within the nursing profession and nursing students need to be taught 
ways of recognizing their own stress levels and stress management. The social support networks of the trauma care nurses is of great importance and the researchers were of the opinion that this area could be explored further. This was supported by Helps (1997) who felt that research in this area would be effective in establishing ways of managing the occupational stress faced by trauma care nurses. As the sample size in this research study was very small, a quantitative research study in this area would be of great interest in order to explore the views of more of the trauma care nurses and pre hospital health care professionals.

\section{Conclusion}

The role of the trauma care nurse in South Africa is challenging, exciting but also extremely stressful due to the violent deaths of a number of clients in the trauma units. Presently the trauma care nurses appear to be aware of the effects that dealing with these deaths is having on them, but are unable to do much to improve their situation. A number of recommendations have been suggested by the participants as well as the researchers and one hopes that these may indeed be attempted before the nursing profession loses these valuable professionals to the ravages of various stress disorders.

\section{Limitations of the study}

A limitation of the study was the withdrawal of a participant from the study (JANE) as well as the problems experienced in trying to interview another participant (MARY), both of these participants were then excluded from further interviews. The fact that the interviews were carried out on duty time could be argued to have influenced the interviews, as the participants were aware that they could be (and often were) called to help with a client. The presence of the researchers could have influenced the participant's responses, as all were aware that the researchers were from an educational institution, and then possibly gave the answers that they thought the researchers would like to hear. The trauma care nurses all appeared to use a particular way of talking and describing incidents to the researchers, they all appeared to have acquired a type of 'trauma slang'. Due to the use of this language it may prove to be quite difficult for a reader, not well versed in the trauma care field, to understand and correctly interpret what the participants were saying. A further limitation of this study was the very small sample size due to the chosen methodology, and thus the researchers are unable to generalize these results beyond the context of this study. 
References

ALDWIN, CM \& REVENSON, TA 1987: Does coping help? A reexamination of the relation between coping and mental health. Journal of Personality and Social Psychology, 53(2): 337-348.

BALDWIN, DV 1998: About trauma. David Baldwin's Trauma Information. [ 8 paragraphs] Available at: http:// www.trauma-pages.com/pg2.htm.

BRINK, HIL 1993: Validity and reliability in qualitative research. Curationis, 16(2): 35 - 38.

BURNS, C \& HARM, NJ 1993: Research Emergency nurses' perceptions of critical incidents and stress debriefing. Journal of Emergency Nursing, 19(5): 431 - 436.

BURNS, N \& GROVE, SK 1995: Understanding nursing research. Philadelphia: W.B. Saunders Company.

COOLICAN, MB 1994: Families. Facing the sudden death of a loved one. Critical Care Nursing Clinics of North America, 6(3): $607-612$.

CORR, CA \& DOKA, KJ 1994: Current models of death, dying, and bereavement. Critical Care Nursing Clinics of North America, 6(3): 545 - 552.

CRESWELL, JW 1998: Qualitative inquiry and research design. Choosing among five traditions. London: Sage Publications.

DIETRICH, TK \& HATTINGH, S 1993: Critical incident stress in emergency service personnel. Trauma \& Emergency Journal, October/November: 943-947.

HATTING, S 1993: Critical incidence stress in emergency service personnel. Trauma \& Emergency Journal, October/ November: 934 - 947.

HELPS, SL 1997: Experiences of stress in Accident and Emergency nurses. Accident and Emergency Nursing, 5: 48 53.

KERR, D 1996: The use of action research as an appropriate method of introducing and evaluating change in nursing care in an accident and emergency unit in Durban - Part 2. Curationis, 19(4): 7-12.

MAEVE, MK 1998: Weaving a fabric of moral meaning: how nurses live with suffering and death. Journal of Advanced Nursing, 27: $1136-1142$.

MANGINI, L; CONFESSORE, MT; GIRARD, P \& SPADOLA, T 1995: Pediatric trauma support programme. Critical Care Clinics of North America, 7(3): 557 - 567.

MARAIS, S 1998: National Trauma Research Programme (NTRP) of the South African Medical Research Council. Violence in South Africa. Trauma Review, 6(2): 1\&10.
MCQUAY, JE; SCHWARTZ, R; GOLDBLATT, P \& GIANGRASSO, VM 1995: "Death-telling" research project. Critical Care Nursing Clinics of North America, 7(3): 549 555.

MEUMANN, C \& PEDEN, M 1997: National Trauma Research Programme (NTRP) of the South African Medical Research Council. The Durban metropolitan pilot study. Trauma Review, 5(1): 1 - 8 .

NEIMEYER, RA 1994: Death anxiety handbook. Washington: Taylor \& Francis.

PAYNE, SA; DEAN, SJ \& KALUS, C 1998: A comparative study of death anxiety in hospice and emergency nurses. Journal of Advanced Nursing, 28(4): 700 -706.

POLIT, DF \& HUNGLER, BP 1993: Essentials of Nursing Research. Methods, appraisal, and utilization. $3^{\text {rd }}$ edition. Philadelphia: Lippincott.

RAPHAEL, B; MELDRUM, L \& MCFARLANE, AC 1996: Does debriefing after psychological trauma work? Time for randomised controlled trials. Accident and Emergency Nursing, 4: $65-67$.

RUBY, D 1998: Sensitivity in traumatic death cases. Tragedy Assistance Programme for Survivors Inc. Selected Articles on Dealing With Grief. [22 paragraphs]. Available at: http: //www.taps.org/griefl.html.

SCHWAM, K 1998: The phenomenon of Compassion fatigue in Perioperative Nursing. AORN Journal, 68(4): 642 648 .

SMITH, C 1995: Bereavement care in A \& E departments. British Journal of Nursing, 4(9): 485-486.

SOLURSH, DS 1990: The family of the trauma victim. Nursing Clinics of North America, 25(1): 155 -162.

STAMM, BH 1998: Traumatic stress \& secondary traumatic stress. Traumatic stress. [13 paragraphs] Available at: http://www.dartmouth.edu/ bhstamm/ts.htm

TYE, C 1993: Cited in Payne, S.A.; Dean, S.J. \& Kalus, C. (1998). A comparative study of death anxiety in hospice and emergency nurses. Journal of Advanced Nursing, 28(4): 700 -706 .

VAN DER MERWE, AS 1996: An epistemological study of the power of woman as nurses - a phenomenological approach. Unpublished Ph.D. Dissertation. Durban: University of Natal.

WHEELER, SR 1996: Helping families cope with death and dying. Nursing 96, July: 25 - 30.

WHITTLE, B 1999: Grief in nursing. Denial \& depression. [16 paragraphs] Available at:

hppt: //www.lis.net.au/ bwhittle/essay.html. 